\title{
CRYSTALLOGRAPHIC STUDY OF CLIFTONITE: A NEW INTERNAL STRUCTURE FOUND IN THE INCLUSION OF THE CAMPO DEL CIELO METEORITE
}

\author{
AKIHIKo OKADA \\ The Institute of Physical and Chemical Research, Wako, Saitama, Japan \\ and \\ MAKoto SHIMA* \\ Max-Planck Institute fïr Chemie, Mainz, West Germany
}

\section{INTRODUGTION}

Cliftonite is a meteoritic mineral of polycrystalline graphite with a cubic morphology. Since it was found in the Magura meteorite by Haidinger and Partsch (1846), the occurrence in meteorites has been reported by many workers, and fourteen iron meteorites, one enstatite chondrite and one mesosiderite have been known up to the present time (Mason, 1962; Ramdohr, 1963; Marvin and Klein, 1964; El Goresy, 1965; Brett and Higgins, 1969). But the origin of cliftonite has been a controversial problem for a long time. Rose (1863), Urey $(1956,1966)$ and Carter and Kennedy (1964) stated that cliftonite is a pseudomorph originated from diamond. But GrenvilleWells (1952), Lipschutz and Anders (1964), El Goresy (1965), Anders and Lipschutz (1966) and Brett and Higgins (1967, 1969) criticized diamond ancestry of cliftonite.

There have been only a few reports on the crystallographic studies of cliftonite. Grenville-Wells showed by X-ray rotation and pinhole transmission photographs that cliftonite of the Youndegin meteorite has a c-axis of graphite parallel to the morphological cube axes. The result is not in agreement with the graphitized diamond which has a c-axis of graphite parallel to $\langle 111\rangle$ - or $\langle 112\rangle$-axes of the original diamond (Grenville-Wells, 1952; Evans and James, 1964). Brett and Higgins (1969) reported that precession X-ray studies of cliftonite from the Canyon Diablo meteorite showed the same result as the conclusion of GrenvilleWells (1952).

Recently the authors have found a new preferred orientation by X-ray studies of cliftonite in the Campo del Cielo meteorite that the c-axis of graphite is approximately parallel to $\langle 113\rangle$-axes of the cubic morphology.

\section{Sample Description}

Samples of the Campo del Cielo meteorite are given by Dr. Kohman (No. 122, CIT No. M-64) and Prof. Hintenberger (El Taco Eiseneinschlüsse AI. 14-15/8). On these samples, cliftonite aggregates are found closely associated with the boundary of graphite inclusions which often include enstatite. It is not clear that these cliftonite grains are of the same form as the graphite polygon. According to Park et al. (1966), the graphite polygon is not a single crystal but rather aggregates of graphite crystals. They described only about the

(Manuscript received, December, 7, 1971)

* On leave from the Institute of Physical and Chemical Research, Wako, Saitama, Japan 


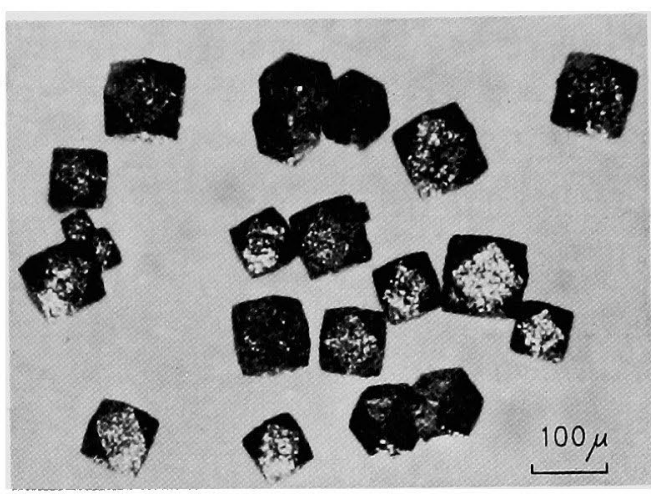

Fig. 1. Cliftonite grains picked out from the Campo del Cielo meteorite. They show a typical morphology of cubooctahedron.

observations and not about the measurement of the internal structure of polygons. The occurrence of cliftonite is simillar to that described by Park et al. (1966) on polygons.

Fig. 1 shows a photograph of cliftonite grains which are separated from graphite inclusions. The cliftonite is $10 \mu$ to $100 \mu$ in size and assumes a typical form of cubooctahedron bounded by $\{100\}$ and $\{111\}$ faces. Under a microscope, the color is greyish black and the luster is rather metallic. The composition of cliftonite is assumed to be pure graphite, because the X-ray powder pattern shows no other diffraction lines except those of graphite. The chemical composition is analyzed semiquantitatively by emission spectroscopy. Trace amounts of elements ( $\mathrm{Fe}, \mathrm{Si}, \mathrm{Mg}, \mathrm{Ni}, \mathrm{Al}$, $\mathrm{Ca}, \mathrm{Cr}, \mathrm{Ti}$ and $\mathrm{B}$ ) are detectable, but they are less than $10 \mathrm{ppm}$.

\section{X-RAY STUDY}

Specimens of the most typical cubooctahedron, $100 \mu$ in size, are selected under the microscope and studied by the $\mathrm{X}$-ray pinhole transmission method as well as by the oscillation method using a Weissenberg camera with Mo $\mathrm{K} a(0.710 \AA)$, Cu Ka $(1.542 \AA), \mathrm{Fe} \mathrm{K} \alpha(1.937 \AA)$ and $\mathrm{Cr} \mathrm{K} \alpha$ $(2.229$ A) radiations. Fig. 2 shows a photograph taken by setting the specimen so that the [001]-axis is vertical and the [110]axis is parallel to the $\mathrm{Cu} \mathrm{Ka}$ beam. As cliftonite is polycrystalline aggregates of graphite, the Debye-Scherrer pattern of graphite is recorded on the film. The Debye-Scherrer ring of Fig. 2 corresponds to the strongest diffraction line indexed as (0002) of graphite. The ring seen in Fig. 2 exhibits maximum and minimum intensities. Therefore it comes to the conclusion that the graphite crystallites are not randomly oriented in cliftonite. The same non-random orientation is also observed on the oscillation photographs.

Preffered orientation is described by a stereographic projection of pole density distribution inferred from the intensity

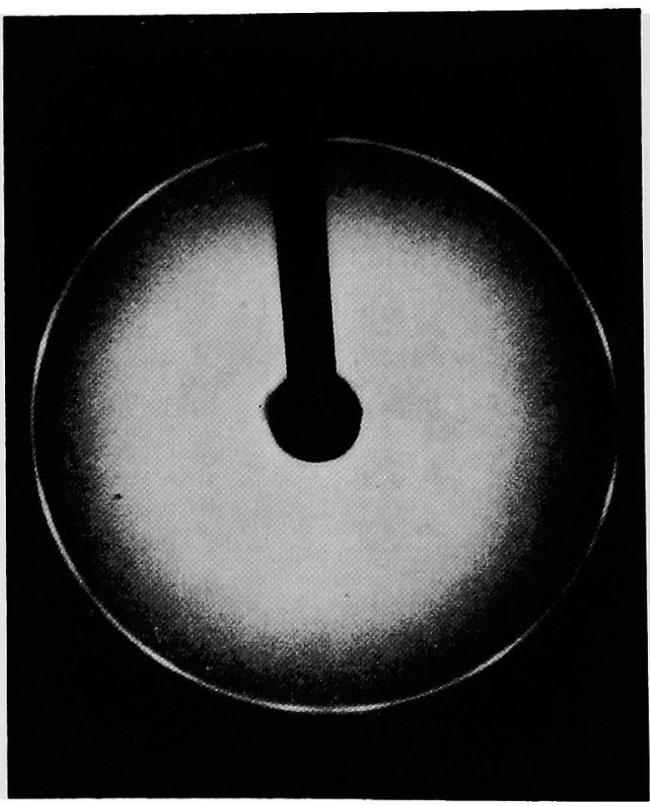

Fig. 2. A pinhole transmission photograph of cliftonite. $\mathrm{Cu} \mathrm{Ka}$ beam is approximately parallel to the $[110]$-axis, and the $[001]$-axis is vertical to the incident beam. 


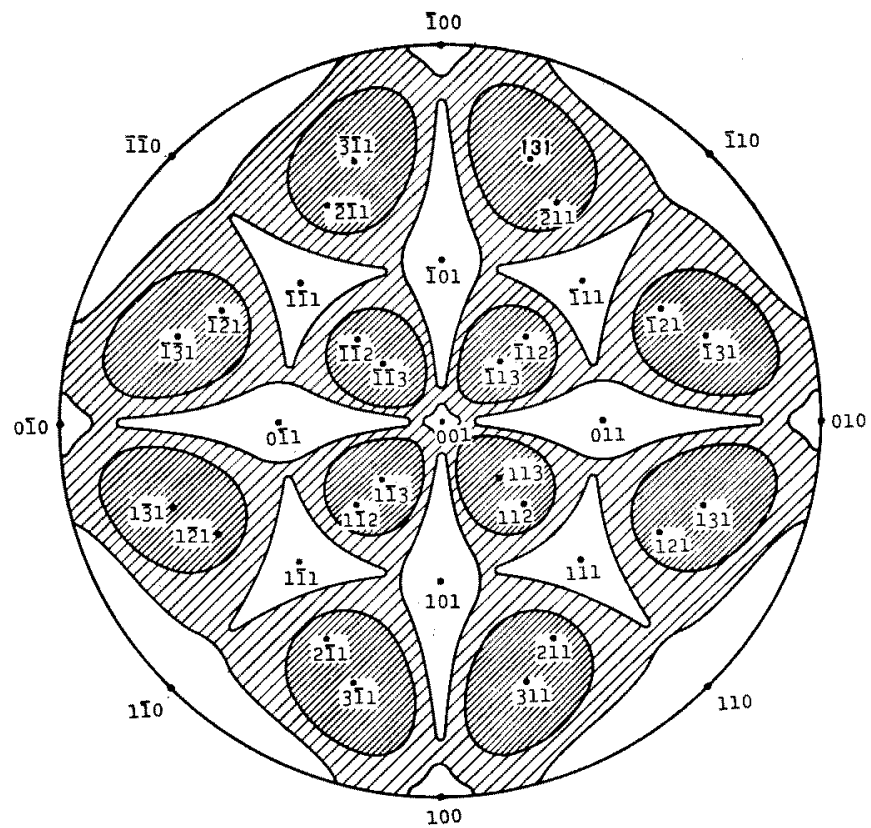

Fig. 3 A pole figure of cliftonite. Pole density distribution of (0002) of graphite is highest in the ranges centered in $\langle 113\rangle$ and absent in the ranges centered in $\langle 100\rangle,\langle 110\rangle$ and $\langle 111\rangle$.

distribution along the Debye-Scherrer ring of pinhole transmission photographs. By varying the incident angle of the $\mathrm{X}$-ray beam, the intensity in the diffraction ring is plotted in the stereographic net. The result is shown in Fig. 3. From the diagram, it is deduced that the distribution of pole density shows the highest density in the ranges centered in $\langle 113\rangle$, and that it is absent in the ranges centered in $\langle 100\rangle$, $\langle 110\rangle$ and $\langle 111\rangle$. As the Debye-Scherrer ring corresponds to the diffraction line indexed as (0002) of graphite, it follows that the c-axis of graphite is preferentially oriented in parallel to the $\langle 113\rangle$-axes of cliftonite.

\section{Discussion}

The present observation of cliftonite from the Campo del Cielo meteorite is of interest on the point that cliftonite has the $\langle 113\rangle$-preferred orientation of the c-axis of graphite as well as the $\langle 001\rangle$-orientation found by Grenville-Wells (1952). On the origin of cliftonite, many investigator have proposed various hypotheses. Rose (1863), Urey $(1956,1966)$ and Carter and Kennedy $(1964,1966)$ pointed out the diamond ancestry of cliftonite. Their view are mainly based on the composition and the external appearance of cliftonite. Carter and Kennedy $(1964,1966)$ argued from the associated occurrence of diamond and cliftonite in the Canyon Diablo meteorite. However, in the studies of surface graphitization of diamond, Grenville-Wells (1952) found that the c-axis of graphite is preferentially oriented along the $\langle 111\rangle$-axes of the original diamond. Evans and James (1964) studied in further detail and observed the another type of preferred orientation with the caxis in a $\langle 112\rangle$ direction. These results and the present observations suggest that cliftonite is not a pseudomorph originated from 
diamond.

Lipschutz and Anders (1961), Anders (1964), and Anders and Lipschutz (1966) argued that cliftonite was derived from some iron carbide. El Goresy (1965) supposed that it was originated from an unknown mineral. But their evidences have not yet been proposed. Recently Brett and Higgins (1967, 1969) synthesized cliftonite-like aggregates in $\mathrm{Fe}-\mathrm{Ni}-\mathrm{C}$ alloy at a normal pressure and criticized the hypothesis of Urey $(1956,1966)$ and Carter and Kennedy (1964) that cliftonite was a transformation product from diamond generated in the meteorite at high static pressure. But the internal structure of the synthetic material has not been investigated.

The present observations by the film method give a qualitative representation of pole distribution in the oriented polycrystalline sample. A more detailed description of texture pattern should be given by the counter-diffractometer techniques. However, it was recognized that cliftonite has two different types of internal structure. This result may suggest that the two kinds of cliftonite have different processes of genesis and growth, and that the inclusion of the Campo del Cielo meteorite has a different mechanical and thermal history from that of the Youndegin meteorite and the Canyon Diablo meteorite. From the chemical composition of silicate inclusions in iron meteorites, Olsen and Jarosewich (1970) also suggested that the formation of these inclusions have a different history.

AGKNOWLEDGMENTs; The authors are grateful to Prof. H. Hintenberger (MaxPlanck Institut für Chemie) for discussions concerning the Campo del Cielo meteorite and to Dr. T.P. Kohman (Carnegie-Mellon University, Pittsburgh) for specimens used in this study.

\section{REFERENCES}

Anders, E. (1964), Origin, age and composition of meteorites. Space Sci. Rev., 3, 583-714. and Lipschutz, M.E. (1966), Critique of paper by N.L. Carter and G.C. Kennedy, "Origin of diamonds in the Canyon Diablo and Novo Urei meteorites." J. Geophys. Res., 71, 643-661.

Brett, R. and Higgins, G.T. (1967), Cliftonite in meteorites: A proposed origin. Science, 156, 819-820.

proposed origin, and its bearing on the origin of diamond in meteorites. Geochim. Cosmochim. Acta, 33, 1473-1484.

Carter, N.L. and Kennedy, G.C. (1964), Origin of diamonds in the Canyon Diablo and Novo Urei meteorites. J. Geophys. Res., 69, 24032421.

and (1966), Origin of diamonds in the Canyon Diablo and Novo Urei meteorite. A reply. J. Geophys. Res, 71, 663-672.

El Goresy, A. (1965), Mineralbestand und Strukturen der Graphit- und Sulfideinschlüsse in Eisenmeteoriten. Geochim. Cosmochim. Acta, 29, 1131-1151.

Evans, T. and James, P.F. (1964), A study of the transformation of diamond to graphite. Proc. Roy. Soc. (London), A277, 260-269.

Grenville-Wells, H.J. (1952), The graphitization of diamond and the nature of cliftonite. Mineral. Mag., 29, 803-816.

Haidinger, W.K. and Partsch, P. (1846), Pseudomorph nach Schwefelkies. Ann. Phys. (Poggendorf), 67, 437-439.

Lipschutz, M.E. and Anders, E. (1961), The record in the meteorites. IV. Origin of diamonds in the iron meteorites. Geochim. Cosmochim. Acta, 34, 83-105.

Marvin, U.B. and Klein, C. Jr. (1964), Meteoritic zircon. Science, 146, 919-920.

Mason, B. (1962), Meteorites, 274 pp. John Wiley. Olsen, E. and Jarosewich, E. (1970), The chemical composition of the silicate inclusions in the Weekeroo Station iron meteorite. Earth Planet. Sci. Letters, 8, 261-266.

Park, F.R., Bunch, T.E. and Massalski, T.B. (1966), A study of the silicate inclusions and other phase in the Campo del Cielo meteorite. Geochim. Cosmochim. Acta, 30, 399-414.

Ramdohr, P. (1963), The opaque minerals in stony meteorites. J. Geophys. Res., 68, 20112036.

Rose, G. (1863), Beschreibung und Einteilung der Meteoriten auf Grund der Sammlung im 
mineralogischen Museum zu Berlin. Abh. dtsch. Akad. Wiss. Berlin, 1863, 23-161.

Urey, H.C. (1956), Diamonds, meteorites and the origin of the solar system. Astrophys. J., 124,
623-637.

(1966), Chemical evidence relative to the origin of the solar system. Royal Astron. Soc. Monthly Notices, 131, 199-223.

\title{
クリフトナイトの結晶学的研究—Campo del Cielo 隕石の包有物に 見出された新しい内部構造について
}

\author{
岡田昭彦・島
}

クリフトナイトは多結晶質のグラファイトから成る隤石鉱物で, cubic の形態をなしている。Youndegin お よび Canyon Diablo 媍石中のクリフトナイトの結晶学的研究からは, グラファイトのc 軸が立方体の<100> 軸方向に沿って配向している事が認めら机てきたが，Campo del Cielo 椇石中のクリフトナイトは前記の結果 と異って、グラファイトの c 軸がはばく113>軸方向に配向している事を見出した。 